\title{
Noch mehr Strandsteine
}

Anmeldt af Mogens K. Hansen, DAGU og Fynske fossilsamlere

Bogen er en opfølger til Strandsteine fra 2004 fra samme forlag og denne gang med 70 sider mere, hvor endnu flere blokke vises og beskrives. Samme koncept som i Strandsteine følges med en side til hver omtalt strandsten. En farvet bjælke for stengruppe, farvefoto af stenen, navn, beskrivelse (alder, hjemsted, matrix-sammensætning, kornstørrelser, fundhyppighed mm.) samt ofte et lille kort med markeret oprindelsesområde for den enkelte sten. I den nye bog er fund fra Nordsøen/ Vesterhavet taget med.

Strandsteine beskrev 110 strandsten. Den nye bog beskriver 177 . Disse er som i Strandsteine opdelt i magmatitter (plutonitter og vulkanitter), metamorfitter, sedimenter samt diverse. Fossiler indgår denne gang kun sekundært og under sedimenter.

Med den nye bog forøges mulighederne for at sætte navne på de strandsten, man endnu ikke helt har fået systematiseret. Samtlige stenfotos er yderst illustrative og fremmer en mulig bestemmelse, når der ses bort fra lokale varianter.

\section{Indhold}

Af 42 viste plutonitter omtales 3 bornholmske granittyper. Af 50 vulkanitter omtales 2 Østersø porfyrer samt 4 skånske: hyperit, NV-dolorit, ankaramit og Brevik-diabas. Af 15 metamorfitter omtales bornholmsk stribet gnejs og 6 skånske typer bl.a. granulit, coronit og stribet Hälleflint.

Udgangsområder er Oslofeltet, Mellemsverige, Ø-Sverige,,$\varnothing$-Sverige, nordlige Østersø, Botniske bugt, SV-Finland og Bornholm. (I bogens efterskrift takkes Per Smed, Klaus-Dieter Meyer og Roland Vinx for bestemmelse af de krystalline blokke).

67 sedimenter omtales, og disse er nok boges største aktiv. I modsætning til dansk palæontologi, har tysk palæontolgi (Geschiebe-forskning: istranport af alt materiale fra stort til småt) en større forskningstradition, idet man inddrager sedimenters oprindelse og fossilfaunaen. Man skelner

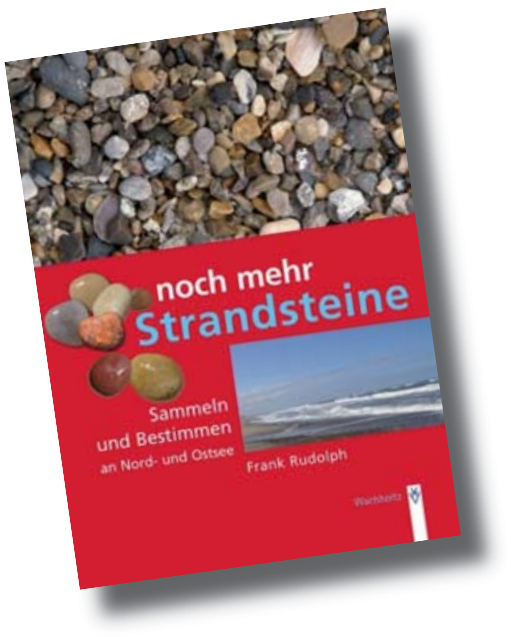

mellem de geologiske perioders forskellige sedimentationer, fx ceratopyge-kalk, planlimbata-kalk og nedre rød orthoceratit-kalk (alle nedre Ordovicium). Under sedimenter beskrives tillige breccier, tillit, konglomerater og gagat.

Udgangspunkt er de krystalline blokke, men med enkelte blokke fra det nordlige Sverige og Norge, de baltiske områder, sydlige Østersø, Danmark og Nordtyskland. Fra det danske område beskrives 16-18 sedimenter bl.a. grøn bornholmsk skifer, sort orthoceratit-kalk, jurassiske kalksandsten (Skagerrak), bornholmsk "kvartsit”; fra øvre Kridt (flintbreccie); Paleocæn (Saltholmkalk, bryozo-kalk, echinoderm-konglomerat); Oligocæn (septarieler); Miocæn og frem (flintkonglomerat);15 blokke tilskrives Skåne. Ældste viste sedimenter er 1,65 mia. år gamle, Digerberg-konglomerat fra Dalarna.

De viste 177 blokke dækker en tidsperiode på 2,0 milliarder år. De ældste er Vänge-granit (1,95 mia.), Sörmland gnejs (1,85-1,95 mia.), rød-grøn Järna granit (1,87 mia.), og stribet Hälleflint (1,8-2,0 mia.). Yngst er Nordstrand kuger (under 3.000 år) og "hekseskåle" (lerjernstenskonkretioner, 5-20 millioner år).

Forord og indføring i bogen underbygger bogens koncept; stor vægt lægges netop på kendskabet til sedimenterne samt flere almindelige krystalline blokke og enkelte mere sjældne. Der redegøres kort for Skandinaviens geologi, istidens spor med større sten, ledeblokkeforskning, værktøj til strandture, fossiler og sedimenter, opbygning af samlinger samt ikke mindst 10 sider omkring bestemmelse af krystalline blokke, heriblandt de forskellige mineralkorn.

\section{En bog mere?}

Tillægget omfatter ikke mindre end 7 tidstavler, link til internetsider, en god litteraturliste med flere skandinaviske titler samt lidt omkring forfatteren, Frank Rudolph. Det fremgår ikke, at han ofte besøger Skandinavien. Men det fremstår indirekte i beskrivelserne af de omtalte strandsten

Skulle der komme en bog 3 , vil også den være til særdeles god hjælp. Den billige bogpris vil også nå flere brugere i Tyskland og i Skandinavien

Geschiebe-forskning (s. 14-15) er et vigtigt element, og følgende forskere nævnes (for videre læsning): L. von Buch, G.A. Brückner, N.G. Sefström, Otto Torrell, L. Agassiz, Kurt Hucke og Roger Schallreuter.

Ting får kun betydning gennem iagttagelser, erkendelse, ny viden og dokumentation. Netop derfor kan bl.a. strandsten bestemmes.

Noch mehr Strandsteine (Sammeln und bestimmen an der Nord- und Ostseeküste und im Binnenland) af Frank Rudolph. Wachholtz Verlag, Neumünster 2008, 224 s, $€ 16,80$. ISBN 978-3-529-05421-1. (bogen kan bl.a. bestilles gennem Frank Rudolph Verlag - www.fossilbuch.de) 